\title{
VITAMIN D AS ONE OF PREDICATORS OF THE STABLE VIRAL RESPONSE TO ANTIVIRAL THERAPY IN PATIENTS WITH CHRONIS HEPATITIS C
}

\author{
Larisa Moroz \\ Department of Infectious Diseases with Epidemiology course \\ Vinnitsa National Pirogov Memorial Medical University \\ 56 Pirogov str., Vinnitsa, Ukraine, 21018 \\ larisa652002@yahoo.com \\ Musaev Eltun Engibar Ogli \\ Department of Infectious Diseases with Epidemiology course \\ Vinnitsa National Pirogov Memorial Medical University \\ 56 Pirogov str., Vinnitsa, Ukraine, 21018 \\ Olga Androsova \\ Department of Infectious Diseases with Epidemiology course \\ Vinnitsa National Pirogov Memorial Medical University \\ 56 Pirogov str., Vinnitsa, Ukraine, 21018 \\ Irina Davydyuk \\ Department of Infectious Diseases with Epidemiology course \\ Vinnitsa National Pirogov Memorial Medical University \\ 56 Pirogov str., Vinnitsa, Ukraine, 21018
}

\begin{abstract}
Chronic hepatitis $\mathrm{C}(\mathrm{CHC})$ it is not exceptionally medical problem but a significant social and economic threat, taking into account the unfavorable consequences of this disease: cirrhosis and hepatocellular carcinoma. And as a result - the high level of disability. In the article are presented the results of examination of 41 patients with chronic hepatitis $\mathrm{C}$, with 1 genotype, who received the antiviral therapy (AVT). All patients underwent determination of the level of 5-hydroxycholecalceferol (25-OH vit $\left.\mathrm{D}_{3}\right)$, vitamin $\mathrm{D}$ and also the study of IL-28B polymorphism as the one of predicators of response to AVT. It was demonstrated, that in patients with hepatitis was observed the deficit of $25-\mathrm{OH}$ vit $\mathrm{D}_{3}$ and general vitamin $\mathrm{D}$. It was established, that in patients with the normal $25-\mathrm{OH}$ vit $\mathrm{D}_{3}$ level SVR (stable viral response) was observed in 1,4 times more often than in patients with deficit of $25-\mathrm{OH}$ vit $\mathrm{D}_{3}$. That is the level of $25-\mathrm{OH}$ vit $\mathrm{D}_{3}$ can be considered as a predicator of SVR to AVT.
\end{abstract}

Keywords: chronic hepatitis C, vitamin D, stable viral response.

DOI: $10.21303 / 2504-5679.2016 .00117$

(C) Larisa Moroz, Musaev Eltun Engibar Ogli, Olga Androsova, Irina Davydyuk

\section{Introduction}

Chronic hepatitis $\mathrm{C}$ is considered by WHO as the serious problem of health protection that is caused by the global widening, long clinical course, unfavorable consequences. According to the WHO data, near 130-150 mln. of population suffer from CHC for today, but it is considered that the real number is significantly larger [1]. By the level of infection Ukraine occupies one of the first places in Europe and there is observed the permanent growth of the CHC morbidity index [2-5]. $\mathrm{HCV}$-infection is characterized with the high rate of chronization with the further risk of formation of cirrhosis and hepatocellular carcinoma and also with systemacy of injuries with development of extra-liver manifestations [6].

According to the modern data, the level and character of infectious process depend on both features of viral antigens and cooperation of all protective mechanisms of macroorganism.

The use of standard AVT gives a possibility to attain the stable viral response (SVR) in patients with $\mathrm{CHC}$, infected with $1 \mathrm{HCV}$ genotype in $42-46 \%$ of cases, infected with $2 / 3 \mathrm{HCV}$ genotype - in 76-82\% [7]. Introduction of preparations with the direct antiviral action into clinical 
practice gave a possibility to raise the effectiveness of AVT in patients with CHC essentially [8, 9]. But the high value of this therapy limits its wide use.

The node question in the treatment of patients with $\mathrm{CHC}$ is the stop of progress of hepatic fibrosis that is the consequence of the different mechanisms of injury of tissue, caused by the viral infection with the final development of cirrhosis and its complications [10]. In this complex of interactions between the hepatic and metabolic factors the share of researches that prove the role of vitamin D as the one of predicators of development and progress of fibrosis among patients with chronic hepatitis $\mathrm{C}$ grows.

The numerous researches in many directions proves the one of the main roles of vitamin $\mathrm{D}$ in the development of pathological processes among patients with $\mathrm{CHC}$, tumor and cardiometabolic disorders and motivated to the further genetic, clinic and experimental researches for the study of metabolism and role of vitamin D [11-13]. Thus, several researches established that the level of vitamin $\mathrm{D}$ in the blood serum can be used as an additional prognostic marker of the stable viral response at standard therapy of viral hepatitis $\mathrm{C}$. Thus, some scientists proved that the low level of 25-OH vitamin $\mathrm{D}_{3}\left(25\right.$-hydroxyvitamin $\mathrm{D}_{3}$ ) was associated with the low level of response to antiviral therapy in such patients [13-15]. In several researches were not revealed interconnections between these indices.

\section{Aim of research}

The study of changes of indices of 5-hydroxycholecalceferol $\left(25-\mathrm{OH}\right.$ vit $\left.\mathrm{D}_{3}\right)$ and general vitamin D in patients with CHC and assessment of their influence on AVT.

\section{Materials and methods of research}

41 patients with $\mathrm{CHC}$ were under observation. Among the examined were 25 (61\%) men, 16 (39\%) women, the mean age of patients was 44,02 $\pm 1,66$ years. All patients were on stationary or outpatient treatment in Vinnitsa city hepatologic center during 2015-2016.

1 genotype was determined in all patients. Most patients had the low viral load $(74,42 \%-$ less than $800000 \mathrm{Ul} / \mathrm{ml}$ ). All patients underwent combined AVT. Interleukin $28 \mathrm{~B}$ was determined in all patients before the start of AVT. Antiviral therapy was realized by the scheme pegylated interferon in combination with ribavirin during 48 weeks in standard dosing. The main aim of CHC treatment was an attainment of SVR that is the absence of RNA VCH at examination by PMR in 24 weeks after the end of complete course of AVT.

The control group included 30 practically healthy persons, 16 men $(53,3 \%)$ and 14 women $(46,7 \%)$, mean age was $35,8 \pm 1,9$ years.

Statistical processing of the received results was carried out using "STATISTICA 5,5" with the help of parametric and nonparametric methods of assessment of the received results. The last one belongs to CRI of Vinnitsa national medical institution of M. I. Pirogov, license № AXXR910A374605FA).

\section{Experimental procedures.}

Diagnosis CHC was proved by detection of anti-HCV-RNA and HCV-RNA in patients' blood serum on analyzers and test-systems: Cobas 6000, Roche Diagnostics (Swiss), Vitrotest (CIS), amplifiers Rotor-Gene («Corbett Research», Australia), TC-AmpliSense (Russia). All examined were infected with virus of 1 genotype.

The levels of 25-hydroxycholecalceferol (25-OH vit $\left.\mathrm{D}_{3}\right)$, general vitamin $\mathrm{D}$, general and ionized calcium and phosphorus were determined in all patients. The level of 25-hydroxycholecalceferol $\left(25-\mathrm{OH}\right.$ vit $\left.\mathrm{D}_{3}\right)$ was determined by the method of chemiluminescence magnetic immune analysis on test-systems ABBOT Diagnostics (USA). The general vitamin D was determined by the method of immune-enzyme analysis using test-systems EUROIMMUN (Germany). The levels of general and ionized calcium and phosphorus were determined on test-systems Roche Diagnostics (Suiss). The complex of examination of patients also included the determination of ALT, AST, general bilirubin levels.

\section{Results of research}

Among patients with CHC men prevailed in 1,6 times (61\%) over women (39\%). Most patients $(43,9 \%)$ were in age diapason of 40-49 years. The least number of patients was younger than 19 years, that was $2,4 \%$ (Fig. 1). 


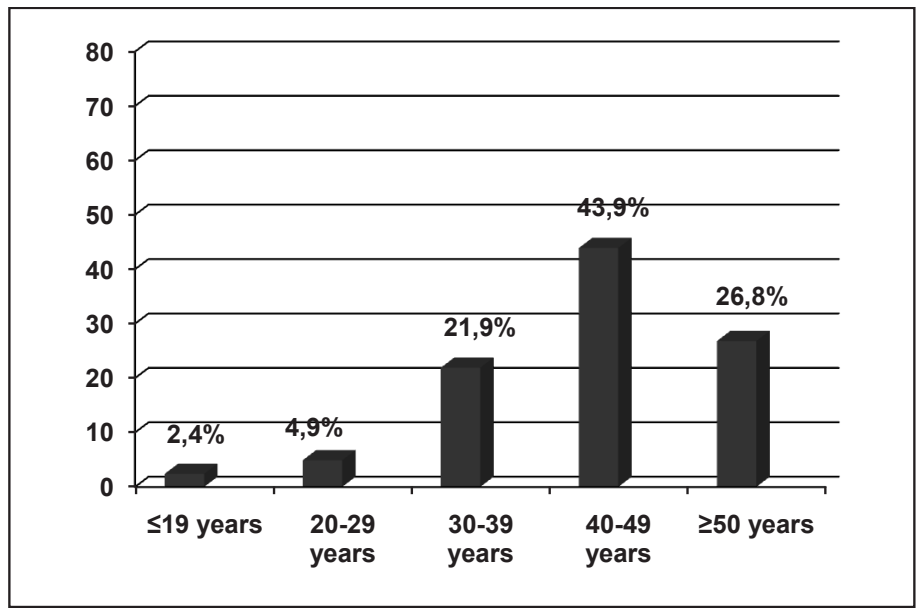

Fig. 1. Distribution of patients with $\mathrm{CHC}$ by age $(n=41)$

Before the start of AVT among patients with CHC prevailed persons with the low level of viral load that were $73,2 \%$ (Fig. 2).

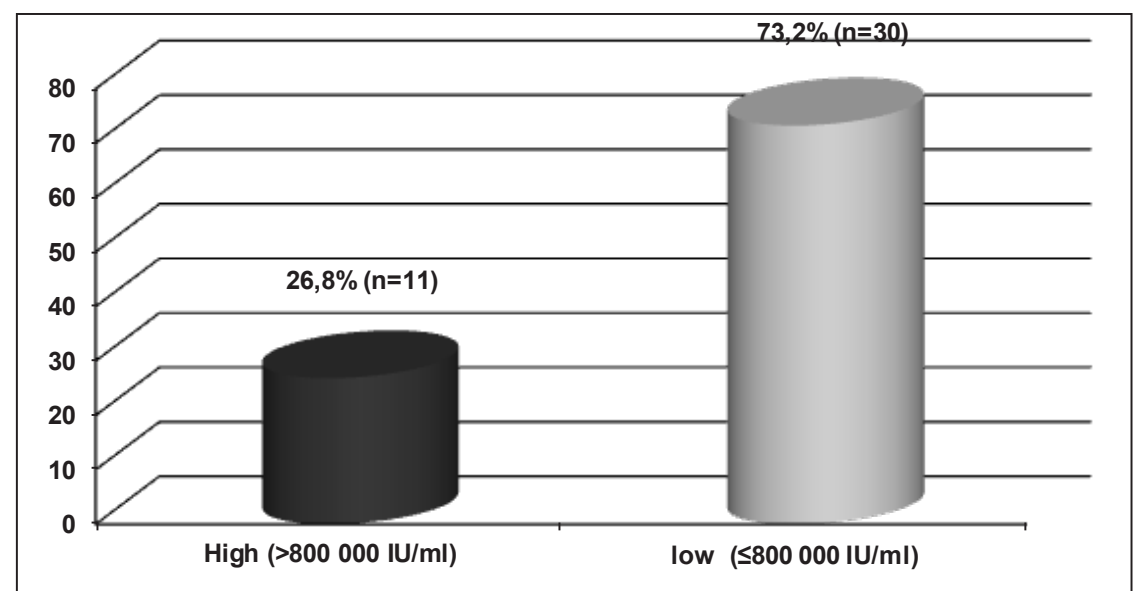

Fig. 2. Distribution of patients with $\mathrm{CHC}$ by the level of viral load

Analyzing the indices of cytolytic syndrome, it was established, that activity of ALT and AST exceeded the referent norms in 1,6 and 1,7 times respectively.

The mean indices of ALT were 1,08 $\pm 0,13 \mathrm{mmol} /$ hour/l and AST - 0,71 $\pm 0,07 \mathrm{mmol} / \mathrm{hour} / \mathrm{l}$.

At comparison of indices of $25-\mathrm{OH}$ vit $\mathrm{D}_{3}$, general vitamin $\mathrm{D}$, general and ionized calcium and phosphorus in patients with $\mathrm{CHC}$ with the ones of healthy persons the reliable difference was detected only between indices of $25-\mathrm{OH}$ vit $\mathrm{D}_{3}$ and general vitamin $\mathrm{D}$. Thus, the level of vitamin $\mathrm{D}$ was in 1,3 times higher in healthy persons comparing with patients with $\mathrm{CHC}$ and the level of $25-\mathrm{OH}$ vit $\mathrm{D}_{3}$ in 1,9 times respectively (Table $\mathbf{1}$ ).

At analysis of indices of $25-\mathrm{OH}$ vit $\mathrm{D}_{3}$ in patients with $\mathrm{CHC}$ it was established, that in overwhelming majority of patients was deficit of $25-\mathrm{OH}$ vit $\mathrm{D}_{3}$, that was $85,4 \%$ of persons. Whereas the normal level of $25-\mathrm{OH}$ vit $\mathrm{D}_{3}$ was observed only in 6 patients that was $14,6 \%$ (Fig. 3).

As to polymorphism of interleukin $28 \mathrm{~B}$ as the one of predicators of SVR in patients with $\mathrm{CHC}$, it was established, that $\mathrm{CT}$ genotype was determined in overwhelming majority of patients that was $65,9 \%$ (27 persons), CC - in 19,5\% (8 persons). The least number of patients had TT genotype that was $14,6 \%$ (6 persons).

We analyzed the response on AVT depending on $25-\mathrm{OH}$ vit $\mathrm{D}_{3}$ level. It was revealed, that in patients with the normal $25-\mathrm{OH}$ vit $\mathrm{D}_{3}$ level SVR was observed almost in $68,3 \%$ of patients against $31,7 \%$ of ones with deficit of $25-\mathrm{OH}$ vit $\mathrm{D}_{3}$ (Fig. 4). 
Table 1

Distribution of patients with $\mathrm{CHC}$ depending on indices of $25-\mathrm{OH}$ vit $\mathrm{D}_{3}$, general vitamin $\mathrm{D}$ and ionized calcium, phosphorus

\begin{tabular}{ccc}
\hline Indices & Patients with $\mathbf{C H C}(\mathbf{n}=\mathbf{4 1})$ & Healthy $(\mathbf{n}=\mathbf{3 0})$ \\
\hline General vitamin $\mathrm{D}, \mathrm{ng} / \mathrm{ml}$ & $27,99 \pm 1,45^{*}$ & $37,54 \pm 1,45$ \\
25-OH vit $\mathrm{D}_{3}, \mathrm{ng} / \mathrm{ml}$ & $20,29 \pm 1,38^{*}$ & $38,54 \pm 1,02$ \\
General calcium (serum), $\mathrm{mmol} / \mathrm{l}$ & $2,43 \pm 0,07$ & $2,32 \pm 0,02$ \\
Ionized calcium (serum), $\mathrm{mmol} / \mathrm{l}$ & $1,25 \pm 0,01$ & $1,28 \pm 0,04$ \\
Phosphorus, $\mathrm{mmol} / \mathrm{l}$ & $1,09 \pm 0,04$ & $1,15 \pm 0,01$
\end{tabular}

Note: $p<0,05$ - reliable difference between groups

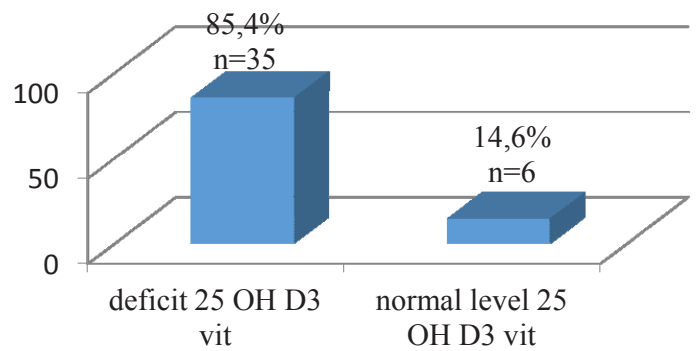

Fig. 3. Distribution of patients with $\mathrm{CHC}$ depending on $25-\mathrm{OH}$ vit $\mathrm{D}_{3}$ level

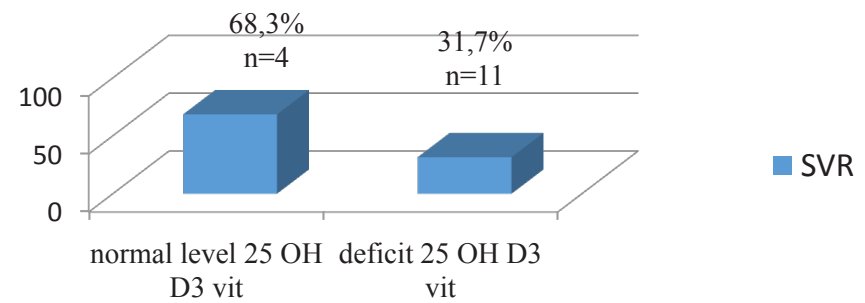

Fig. 4. Distribution of patients with $\mathrm{CHC}$ depending on $25-\mathrm{OH}$ vit $\mathrm{D}_{3}$ level and response to AVT

\section{Discussion of the results of research}

The researchers pay more and more attention to the IL-28B, which gene polymorphism is a reliable prognostic criterion of the effectiveness of treatment of hepatitis $C$ [16]. There was established the prevalence of different polymorphisms of gene of this cytokine among Ukrainians. Thus, SNP CC rs12979860 was revealed in $56 \%$, CT - in $34 \%$, TT - in $10 \%$ of examined, whereas the frequency of revelation of CC rs12979860 allele among patients with chronic HC is significantly lower that is $36,8 \%$ [17], that is possibly connected with the more frequency of spontaneous $\mathrm{HCV}$ clearance after the acute form of infection.

In our research at the study of polymorphism of interleukin $28 \mathrm{~B}$ among patients with $\mathrm{CHC}$ was established that CT genotype is most frequent - in $65,9 \%$ of persons.

It was revealed that $25-\mathrm{OH}$ vit $\mathrm{D}_{3}$ level was in 1,9 times lower in patients with $\mathrm{CHC}$ than the one in healthy persons, whereas the level of general vitamin D only in 1,3 times.

There are the contradictory data about connection of vitamin D with the progress of CHC. According to the data of several authors, the deficit of vitamin D can influence the effectiveness of AVT and the progress of disease [18]. According to the data of other authors, there were not revealed any differences in the level of vitamin D depending on stage of fibrosis and sensitivity to AVT in patients with CHC [19].

In the other research was revealed that the frequency of SVR among patients of Caucasian race correlated with $25-\mathrm{OH}$ vit $\mathrm{D}_{3}$ level, whereas the frequency of SVR was higher in patients with normal or heightened $25-\mathrm{OH}$ vit $\mathrm{D}_{3}$ level (SVR was observed in $46 \%$ of patients at the normal concentration of $25-\mathrm{OH}$ vit $\mathrm{D}_{3}$ in blood serum; $\mathrm{p}=0,008$ ) [20].

We revealed that in patients with the normal $25-\mathrm{OH}$ vit $\mathrm{D}_{3}$ level SVR was observed in 1,4 times more often than in patients with deficiency of $25-\mathrm{OH}$ vit $\mathrm{D}_{3}$. 


\section{Conclusions}

1. In patients with $\mathrm{CHC}$ comparing with practically healthy persons the deficit of $25-\mathrm{OH}$ vit $\mathrm{D}_{3}$ and general vitamin $\mathrm{D}$ was detected reliably more often in 1,9 and 1,3 times respectively.

2. It was detected, that after the end of AVT in patients with CHC SVR was observed reliably $(\mathrm{p}<0,05)$ more often $(68,3 \%)$ in persons who have the normal $25-\mathrm{OH}$ vit $\mathrm{D}_{3}$ level.

\section{References}

[1] WHO Bulletin (2014). World Health Organization, 164.

[2] Golubovska, O. A., Lischyshyna, O. M., Andreychyn, M. A. et. al. (2014). Viral Hepatitis C: Clinical adapted guidance based on evidence. The application to the Ministry of Health of Ukraine 02.04.2014; № 233, 90.

[3] Wovk, A. D. (2007). Clinical problem and the treatment of chronic hepatitis C. Ukr. med. Journal, 1, 50-54.

[4] Ghany, M. G., Strader, D. B., Thomas, D. L., Seeff, L. B. (2008). Diagnosis, management, and treatment of hepatitis C: An update. Hepatology, 49 (4), 1335-1374. doi: 10.1002/hep.22759

[5] Mauss, S., Berg, T., Rockstroh, J. et. al. (2012). Short Guide to Hepatitis C. Flying Publisher, 150.

[6] Ignatova, T. M., Aprosina, Z. G., Serov, V. V. (2001). Extrahepatic manifestations of chronic HCVinfection. Rus. Med. Journal, 2, 13-18.

[7] Anastasiy, I. A. (2007). World experience in the treatment of patients with chronic hepatitis C. Infectious diseases, 3, 102-103.

[8] Agnello, V., De Rosa, F. G. (2004). Extrahepatic disease manifestations of HCV infection: some current issues. Journal of Hepatology, 40 (2), 341-352. doi: 10.1016/j.jhep.2003.10.009

[9] Guida, M., D’Elia, G., Benvestito, S., Casamassima, A., Micelli, G., Quaranta, M. et. al. (2002). Hepatitis C virus infection in patients with B-cell lymphoproliferative disorders. Leukemia, 16 (10), 2162-2163. doi: 10.1038/sj.leu.2402626

[10] Bueverov, A. O., Maevskaya, M. V. (2008). Chronic hepatitis C and associated liver pathology. Clinic. prospects. gastroenterol. hepatol, 6, 9-15.

[11] Shakhgildyan, I. V., Jasinski, A. A., Mikhailov, M. I. et. al. (2008). Chronic hepatitis in the Russian Federation. Epidemiology and Infectious Diseases, 6, 12-15.

[12] Iacob, S. A., Banica, D., Panaitescu, E. et. al. (2010). Positive correlation of 25-hydroxyvitamin D plasma level and $\mathrm{T}$ helper activity in chronic hepatitis $\mathrm{C}$ patients. International Journal of Biology and Biomedical engineering, 4 (2), 43-51.

[13] Arteh, J., Narra, S., Nair, S. (2009). Prevalence of Vitamin D Deficiency in Chronic Liver Disease. Digestive Diseases and Sciences, 55 (9), 2624-2628. doi: 10.1007/s10620-009-1069-9

[14] Rahman, A. H., Branch, A. D. (2013). Vitamin D for your patients with chronic hepatitis C? Journal of Hepatology, 58 (1), 184-189. doi: 10.1016/j.jhep.2012.07.026

[15] Ladero, J. M., Torrejon, M. J., Sanchez-Pobre, P. (2013). Vitamin D deficiency and vitamin D therapy in chronic hepatitis C. Annals of Hepatology, 12, 199-204.

[16] Suppiah, V., Moldovan, M., Ahlenstiel, G., Berg, T., Weltman, M., Abate, M. L. et. al. (2009). IL28B is associated with response to chronic hepatitis $\mathrm{C}$ interferon- $\alpha$ and ribavirin therapy. Nature Genetics, 41 (10), 1100-1104. doi: 10.1038/ng.447

[17] Pampukha, V. M., Kravchenko, S. A., Moroz, L. V., Livshits, L. A. (2011). IFN-\&lambda; -3 (IL28B) genotyping by restriction fragment length polymorphism method: detection polymorphism of rs12979860. Biopolymers and Cell, 27 (3), 231-234. doi: 10.7124/bc.0000be

[18] Gal-Tanamy, M., Bachmetov, L., Ravid, A., Koren, R., Erman, A., Tur-Kaspa, R., Zemel, R. (2011) Vitamin D: An innate antiviral agent suppressing hepatitis C virus in human hepatocytes. Hepatology, 54 (5), 1570-1579. doi: 10.1002/hep. 24575

[19] Corey, K. E., Zheng, H., Mendez-Navarro, J., Delgado-Borrego, A., Dienstag, J. L., Chung, R. T. (2012). Serum Vitamin D Levels Are Not Predictive of the Progression of Chronic Liver Disease in Hepatitis C Patients with Advanced Fibrosis. PLoS ONE, 7 (2), e27144. doi: 10.1371/journal.pone.0027144

[20] Gutierrez, J., Parikh, N., Branch, A. (2011). Classical and Emerging Roles of Vitamin D in Hepatitis C Virus Infection. Seminars in Liver Disease, 31 (04), 387-398. doi: 10.1055/s-0031-1297927 